\title{
REFINING PRODUCT MARKET DEFINITION IN THE ANTITRUST ANALYSIS OF BANK MERGERS
}

\author{
TIM MCCARTHY \\ INTRODUCTION
}

The last decade has seen unprecedented consolidation in the banking industry. 1995 was a record year for bank mergers in terms of both the number of transactions and the dollar value of those transactions. ${ }^{2}$ Antitrust scrutiny of the inergers and acquisitions comprising this consolidation lias also increased, as prospective acquirers have turned from inarket-expanding mergers involving banks in different markets to in-1narket mergers, which remove coinpetitors from a given market and are thus more likely to raise antitrust concerns. ${ }^{3}$

Each prospective bank merger ${ }^{4}$ is subject to review by the Antitrust Division of the Department of Justice, as is true of

1. See Dean F. Amel, Trends in the Structure of Federally Insured Depository Institutions, 82 FED. RES. BULL. 1, 1, 6 (1995). The rate of consolidation in the banking industry has increased fourfold over that period. See Sherrill Shaffer, Bank Competition in Concentrated Markets, Bus. REV. (FED. RESERVE BANK OF PHIIA.), Mar.-Apr. 1994, at 3.

2. See U.S. Bank Deals Led 1995 Merger Activity, Reuters, Dec. 29, 1995, available in LEXIS, Bankng library, Curnws file. The assets involved in bank mergers in 1995-approximately 60 billion dollars-were inore than double the previous record. See Anne K. Bingaman, Antitrust and Banking, 49 ANTITRUst BULL. 465, 467 (1996).

3. See Michael A. Greenspan, Documentation Can Help Blunt Challenges to In-Market Mergers, AM. BANKER, Feb. 15, 1994, at 17; Cynthia A. Glassman, Merger Plans Need Careful Antitrust Analysis, AM. BANKER, June 24, 1992, at 4. "Market-expanding mergers" are mergers between two firms operating in difierent geographic areas, which provide the surviving firm with instant access to a larger geographic market. "In-market mergers" are inergers between firms operating in the same geographic area, which are usually consummated in order to enhance efficiency and lower costs by taking advantage of economies of scale. See W. KIP VISCUSI ET AL., ECONOMICS OF REGULATION AND ANTITRUST 199-207 (2d ed. 1995).

4. Throughout this Note, the term "bank merger" will refer to any merger or acquisition involving two banks, a bank and a bank holding company, two bank holding counpanies, or a bank and a thrift institution in a merger and conversion under 12 U.S.C. $\$ 1815$ (d)(2), (3) (1994). While there are many differences between the regulation of operations of these different conglomerations, the regulation of mergers between them is basically uniform, and the antitrust review of such mergers is almost entirely uniform. 
mergers in other industries. ${ }^{5}$ Bank mergers, however, are also subject to review by the Board of Governors of the Federal Reserve or by one of several other federal banking agencies. ${ }^{6}$ While the federal banking agencies' antitrust review powers derive from different legislation than those of the Antitrust Division, ${ }^{7}$ the basic standard of review established by the federal banking laws is the same as that established by Section 7 of the Clayton Act: ${ }^{8}$ the responsible federal banking agency must not approve any merger which would create a monopoly, would be in furtherance of any combination or conspiracy to monopolize, or would substantially lessen coinpetition or restrain trade in any "section of the country." However, because the Antitrust Division and the federal

5. See Gina M. Killian, Bank Mergers and the Department of Justice's Horizontal Merger Guidelines: A Critique and Proposal, 69 NOTRE DAME L. REV. 857, 859 (1994). Federal law requires that prospective bank mergers be referred to the Antitrust Division for prior review. See Bank Merger Act, 12 U.S.C. \& 1828(c)(4) (1994). The Federal Trade Commission thus does not review bank mergers.

6. The Federal Reserve is responsible for antitrust review of the merger if the surviving bank will be a state-chartered member of the Federal Reserve System, or if either participant in the merger is a bank holding company. See 12 U.S.C. $\$ \$ 1828$ (c), 1842(a) (1994). The Federal Reserve thus has jurisdiction over the hon's share of bank mergers, and will be the primary banking agency referred to in this Note. If the surviving bank is to be a national bank, then the responsible agency is the Comptroller of the Currency (OCC); if the surviving bank is to be a state non-member bank, then the responsible agency is the Federal Deposit Insurance Corporation (FDIC); and if the surviving institution is to be a thrift (i.e., a savings and loan), then the Office of Thrift Supervision (OTS) is to be the reviewing agency. See 12 U.S.C. $\S 1828$ (c).

7. The banking agencies' antitrust review powers derive from the Bank Merger Act, 12 U.S.C. $\& 1828$ (c) (governing mergers between federally-insured commercial banks); the Bank Holding Company Act, 12 U.S.C. $\& 1842(a)$, (c) (governing mergers to which one of the parties is a bank holding coinpany, or of which the resulting institution will be a bank holding company); and the Change in Bank Control Act of 1978, 12 U.S.C. $\$ 1817(\mathrm{j})$ (governing acquisitions by individuals). The Antitrust Division's merger review powers derive primarily from Section 7 of the Clayton Act, 15 U.S.C. $\& 18$ (1994).

8. 15 U.S.C. $\$ 18$.

9. 12 U.S.C. $\$ 1828(c)(5)$ (providing the standard used to determine when a proposed bank merger transaction will be approved under the Bank Merger Act); 15 U.S.C. $\S 18$ (providing the standard used to determine when a proposed business combination is illegal under the Clayton Act). Unlike the Clayton Act, however, the banking laws explicitly provide an escape latch: a merger may be approved if the responsible agency finds that the anticompetitive effects of the proposed merger are outweighed by any positive effects that serve the "convenience and needs" of the community. 12 U.S.C. $\$ 1828(c)(5)(B)$. The Antitrust Division does not consider such "convenience and needs," but does analyze any "countervailing efficiencies" that may result from the merger. See infra notes 33-39 and acconipanying text. Like the "countervailing efficiencies" defense available to merger partners in other industries, the "convenience and needs" defeuse is not a viable hitigation strategy for several reasons: the defense is limited by the same information and cost problems that plague the efficiencies defense, see id:; the burden of 
banking agencies have different missions, the standards and methods of review differ between the two agencies in several respects. ${ }^{10}$

One point on which the Antitrust Division and the Federal Reserve differ is the method for defining the relevant product market to be analyzed. In order to determine whether a prospective merger would lessen competition in a "section of the country, "11 both the Antitrust Division and the Federal Reserve must define a particular section of the country which would be susceptible to any anticompetitive effect that might result from the inerger in question. ${ }^{12}$ This determination requires the agencies to define both a relevant geographic market and a relevant product market. $^{13}$ The relevant geographic inarket is defined as the area in which a hypothetical monopohst could impose an increase in the price of its products without fear that competition would force the monopolist to abandon its atteinpt to increase prices. ${ }^{14}$ The rele-

proving the defense at trial is on the defendant, see United States v. First City Nat'l Bank of Houston, 386 U.S. 361,366 (1967); and the defense is available only when the proposed nierger is necessary to support a weak acquiree bank, see Mid-Nebraska Bancshares v. Board of Governors of the Fed. Reserve Sys., 627 F.2d 266, 271 (D.C. Cir. 1980) (citing United States v. Third Nat'l Bank, 390 U.S. 171 (1968)).

10. See Michael A. Greenspan, Justice and Banking Agencies Still Analyze Bank Mergers Differently, BANKING POL'y REP., Sept. 4, 1995, at 17. A 1982 General Accounting Office review found that "there was no uniformity to the [bank merger review] evaluations nor had specific criteria been developed for making the evaluations. . . This overall lack of uniformity has resulted in conflicting decisions by Federal regulators and subsequent 'agency shopping' by financial institutions." JONATHAN R. MACEY \& GEOFFrey P. MIILER, BANKING LAW AND REgULATION 447 (1992).

Since that time, the Antitrust Division and the federal banking agencies have done much to make the bank inerger review process more uniform and more predictable. However, differences remain: as noted supra note 9, the Division and agencies still use slightly different methods of considering countervailing efficiencies or "convenience and needs." The Division and agencies also use very different methods of product market definition-the subject of this Note. See Robert E. Litan, Deputy Assistant Attorney General, Antitrust Division, U.S. Dep't of Justice, Antitrust Assessment of Bank Mergers, Address Before the Antitrust Section of the ABA (Apr. 6, 1994) available in Speeches by Senior Members of the Antitrust Division (visited Jan. 19, 1997) <http:/www.usdoj.gov/ gopherdata/atr/talks/litan.txt>.

11. 12 U.S.C. $\S 1828(\mathrm{c})(5)(B)$.

12. See 1992 Horizontal Merger Guidelines § 1, 57 Fed. Reg. 41,552, 41,554 (1992) [hereinafter Merger Guidelines]; see also ROGER D. BLAIR \& DAVID L. KASERMAN, ANTITRUST ECONOMICS 237 (1985) (stating that "the courts must decide whether the merger will result in a substantial lessening of competition or tendency to create a monopoly in any line of commerce in any section of the country").

13. See Blair \& KASERMAN, supra note 12 , at 237.

14. See Merger Guidelines, supra note 12 , $\$ 1.21$, at 41,555 ; VISCUSI ET AL., supra 
vant product market similarly is defined as the product or products whose prices the hypothetical monopolist could raise without fear that competition would force it to lower its prices. ${ }^{15}$ In the context of commercial bank mergers, the traditional method of defining the relevant product market has been to include in that market all the products and services traditionally provided by commercial banks, mcluding products such as loans and services such as acceptance of savings and checking deposits and provision of trust services. ${ }^{16}$ This method is still used by the Federal Reserve. $^{17}$ In recent years, however, the Antitrust Division has abandoned this "cluster market" method of product market definition. ${ }^{18}$ It has instead adopted a method of disaggregation of the traditional cluster of bank products and services imto several submarkets, with particular emphasis on the market for commercial lending to small and medium-sized businesses. ${ }^{19}$ Because the Division's method is intended to determine whether any of these several submarkets may be susceptible to anticoinpetitive effects, its scrutiny is now widely regarded as more stringent than that of the Fed. ${ }^{20}$

note 3, at 212-14.

15. See Merger Guidelines, supra note $12, \S 1.11$, at 41,554 ; VISCUSI ET AL., supra note 3 , at 212-14.

16. See United States v. Philadelphia Nat'l Bank, 374 U.S. 321, 326 n. 5 (1963). This method of product market definition is referred to as the "cluster market" method, and is explained further in Part $\mathrm{I}$, infra. Cluster markets also appear in other industries, such as fire and burglar alarm services, see United States v. Grinnell Corp., 384 U.S. 563, 572-73 (1966), acute care hospital services, see American Medicorp, Inc. v. Humana, Inc,, 445 F. Supp. 589, 603-04 (E.D. Pa. 1977), and beauty products, see JBL Enter. v. Jhirmack Enter., 698 F.2d 1011, 1016-17 (9th Cir. 1983).

17. See KeIth R. Fisher, Mergers and acouisitions of Banks and Savings INSTTTUTIONS \& 3.12, at. 3:88-90 (1993); Greenspan, supra note 10, at 17.

18. See infra Section I.B.3.

19. See id. In this Note, the term "submarket" is used to refer to the specific product markets which together might constitute one cluster market. This use of the term is meant to be distinct from its use in Brown Shoe Co. v. United States, 370 U.S. 294 (1962), and its progeny, to refer opaquely to "narrow relevant markets within broader relevant markets," Lawrence C. Maisel, Submarkets in Merger and Monopolization Cases, 72 GEO. L.J. 39, 39, 42-44 (1983-84), which "never had any theoretical justification . . . and created much confusion in the law." Robert Pitofsky, New Definitions of Relevant Market and the Assault on Antitrust, 90 COLUM. L. REV. 1805, 1849 n.182 (1990).

20. See, e.g., Eugene M. Katz, Comment, Justice Department Stance in Hawaii May Be Signal of Merger Fights Ahead, AM. BANKER, Apr. 19, 1991, at 4 (noting that the Antitrust Division's shift to the disaggregative method of product market definition will impact significantly upon consolidation decisions made by American financial institutions). 
Part I of this Note briefly surveys the theoretical background and legal history of the ongoing conflict between the Antitrust Division and the Fed with regard to product market definition in the antitrust analysis of bank mergers. Part II compares and critiques the two approaches to product market definition, noting theoretical and empirical shortcomings of both the Fed's cluster market method of product market definition and the Antitrust Division's disaggregative submarket method. Part III suggests a reconciliation of the two approaches that would ameliorate some of the flaws in each, would offer both the Antitrust Division and the federal banking agencies greater flexibility to account for the effects on competition created by thrifts and other non-bank providers of financial products and services, and would better protect competition and consumers from potential anticompetitive effects of a proposed bank merger.

\section{BACKGROUND}

\section{A. Merger Analysis in General}

The Antitrust Division's general method for determining whether a proposed merger will likely have significant anticompetitive effects is outlined in the 1992 Horizontal Merger Guidelines. ${ }^{21}$ This method is also used by the Fed and the other federal banking agencies. ${ }^{22}$ The analysis begins with the definition of the relevant market. ${ }^{23} \mathrm{~A}$ "market" consists of both a product market and a geographic market, that is:

a product or group of products and a geographic area in which it is produced or sold such that a hypothetical profit-maximizing firm, not subject to price regulation, that was the only present and future producer or seller of those products in that area likely would impose at least a "small but significant and nontransitory" increase in price ["SSNPI"], assuming the terms of sale of all other products are held constant. ${ }^{24}$

21. See Merger Guidelines, supra note $12, \S 0.2$, at 41,554 .

22. See FISHER, supra note 17, \& 3.12.1, at 3:90-98. See also Adoption of Policy Statement, 54 Fed. Reg. 39,043 (1989) (outlining FDIC merger review process, which was adopted after Antitrust Division commented "in considerable detail," and which in many particulars presaged Antitrust Division's 1992 Merger Guidelines).

23. See Merger Guidelines, supra note 12 , § 1, at 41,554.

24. Id. 
The relevant inarket includes only the "group of products and a geographic area that [are] no bigger than necessary to satisfy this test.".25

The constituent product market and geographic market are defined by demand substitution factors, i.e., possible consumer responses to the imposition of an SSNPI. ${ }^{26}$ The relevant geographic market comprises the geographic area where a hypothetical inonopolist could impose an SSNPI without local customers substituting products from other areas for its product and thus forcing the inonopolist to lower its price again. ${ }^{27}$ Similarly, the relevant product inarket is that product or group of products upon whose prices a liypothetical inonopohst could impose an SSNPI without its customers substituting other products for the monopolist's and thus forcing it to lower its prices again. ${ }^{28}$ Product and geographic markets are correctly defined when they "recognize coinpetition where, in fact, competition exists." ${ }^{929}$

25. Id.

26. See id. The SSNPI is usually characterized as a price $5 \%$ above the current level or $10 \%$ above the competitive level. See PHILLIP AREEDA ET AL, ANTTrRUST LAW II 560, at 251 (1995).

27. See Merger Guidelines, supra note $12, \S 1.21$, at $41,555-56$. The definition of product markets is thus based on the cross-elasticity of demand between the product of the potential monopolist and possible substitutes for that product. Cross-elasticity refers to the responsiveness of demand for possible substitutes in response to an increase in the price of the potential monopolist's product; the more responsive the demand for substitutes, the higher the cross-elasticity. See BLAIR \& KASERMAN, supra note 12, at 108-09; United States v. E.I. duPont de Nemours \& Co., 351 U.S. 377, 400 (1956).

28. The product market is defined as those products susceptible to the exercise of market power because it is the exercise of market power that merger review is designed to prevent. See Merger Guidelines, supra note 12, § 0.1, at 41,553, §1.11, at 41,554-555.

The Division utilizes a number of different kinds of evidence of substitutability, including: 1) evidence that buyers have in the past substituted products in response to a price increase; 2) evidence that sellers base business decisions on the prospect that their customers might substitute others' products for theirs; 3) the effects of downstream competition on buyers, such as, the size of buyers' margins on resale of the monopolist's product, and thns the limits of their tolerance for a price increase; and 4) the timing and costs to buyers of switching products. See id. These effects are in turn estimated by raw data from the potential relevant market, such as sales data and traffic patterns. The substitutability of banking products and services can be obscured by the Division's and the Fed's use of deposits as a proxy for market share, instead of addressing market share directly through sales and other data normally utilized in the analysis of mergers in other industries. See infra notes $165-69$ and accompanying text.

29. Brown Shoe, 370 U.S. at 326. While principles of market definition are straightforward in the abstract, their application in antitrust cases is often very problematic. See, e.g., U.S. Healthcare, Inc. v. Healthsource, Inc., 986 F.2d 589, 598 (1st Cir. 1993) ("There is no subject in antitrust law more confusing than market definition."). 
Once the relevant market has been defined, the Antitrust Division and the federal banking agencies first proceed to determine whether or not a proposed merger would significantly increase concentration in the relevant market and result im a high level of concentration in that market. ${ }^{30}$ Second, the Division and the federal banking agencies assess whether the inerger raises concerns about potential anticompetitive effects resulting from increased concentration or other factors. ${ }^{31}$ Third, the Division and the agencies assess whether other firms would be likely to enter the market to compete with the survivor of the inerger and prevent supracompetitive price increases. ${ }^{32}$ Fourth, the Division and the agencies assess any efficiency gains that might result from the merger. ${ }^{33}$ Finally, the Division and the agencies consider the possibility that the inerger may be necessary to prevent the failure of one of the parties. ${ }^{34}$

Market definition is very often determinative of the final outcome. of merger analysis. ${ }^{35}$ The crucial role of market definition is largely due to the considerable costs and information deficits that plague defendants' attempts to present a defense of coun-

30. See Merger Guidelines, supra note $12, \S 1$, at 41,554 .

31. See id. $\$ 2$, at 41,557 .

32. See id. \& 3, at 41,561. A supracompetitive price increase is an increase to a price above that which would prevail if consumers could freely substitute competitors' products for those of the monopolist.

33. This stage opens up the opportunity for prospective inerger partners to assert the "countervailing efficiencies defense": that efficiency gains resulting from the inerger outweigh any possible anticompetitive effects. This defense is rarely successful. See infra notes 35-39 and accompanying text. The Guidelines also require that any efficiency gains to be considered in favor of the proposed inerger could not be achieved by the parties by any other means. See Merger Guidelines, supra note 12, \& 4, at 41,562.

34. See id. $\& 5$, at $41,562-63$.

35. See Donald I. Baker \& William Blumenthal, The 1982 Guidelines and Preexisting Law, 71 CAL. L. REv. 311, 322 (1983); Jonathan B. Baker, The Antitrust Analysis of Hospital Mergers and the Transformation of the Hospital Industry, LAW \& CONTEMP. PROBS., Spring 1988, at 93, 119; James A. Keyte, Market Definition and Differentiated Products: The Need for a Workable Standard, 63 ANTrTRUST L.J. 697, 697 (1995); see, e.g., Rebel Oil Co. v. Atlantic Richfield Co., 51 F.3d 1421, 1434 (9th Cir. 1995) ("Without a definition of the relevant inarket, it is impossible to determine market share."); Fleer Corp. v. Topps Chewing Gum, Inc., 501 F. Supp. 485, 505 (E.D. Pa. 1980), rev'd on other grounds, 658 F.2d 139 (3d Cir. 1981) ("[M]arket definition is crucial to determining the reasonableness or unreasonableness of a firm's market power.").

Adjudication of alleged antitrust violations can proceed without a definition of the relevant market only where there is direct, as opposed to circumstantial, evidence of a violation of antitrust law; such cases are rare. See, e.g., E.W. French \& Sons, Inc. v. General Portland, Inc., 885 F.2d 1392, 1402-06 (9th Cir. 1989) (Farris, J., concurring). 
tervailing efficiencies. ${ }^{36}$ The availability of the efficiencies defense is also limited by the Antitrust Division's requirement that any efficiency gains to be considered in favor of the merger be unavailable through any other means, ${ }^{37}$ by many attorueys' unfamiliarity with the defense, ${ }^{38}$ and perhaps by some reluctance of the courts to give much weight to the efficiencies defense, even when it is credibly argued. ${ }^{39}$

\section{B. Historical Background}

1. Rise of the Cluster Market Approach. The cluster market approach to product market definition in the antitrust analysis of bank mergers was first outlined by the Supreme Court im United States v. Philadelphia National Bank im 1963. ${ }^{40}$ The Court in Philadelphia National stated that:

[T] he cluster of products (various kinds of credit) and services (such as checking accounts and trust administration) denoted by the term "commercial banking," . . . composes a distinct line of commerce. Some commercial banking products or services are so distinctive that they are entirely free of effective competition from products or services of other financial institutions; the checking account is im this category. Others enjoy such cost advantages as to be insulated within a broad range from substitutes furnished by other institutions. ... Finally, there are banking facilities which, although in terms of cost and price they are freely competitive with the facilities provided by other financial

36. See Dennis A. Yao \& Thomas N. Dahdouh, Information Problems in Merger Decision Making and Their Impact On Development of an Efficiencies Defense, 62 ANTITRUST L.J. 23 (1993). "[I]nformation problems . . . often present major hurdles to merger proponents presenting efficiencies claims to antitrust enforcers," and "may present major hurdles ... in litigation as well, since case law imposes on merger proponents the burden of production and persuasion of efficiencies...."Id. at 29 \& n.19. The "convenience and needs" defense provided by the federal banking laws suffers from the same problems that have rendered the efficiencies defense impotent. See supra note 9.

37. See Merger Guidelines, supra note $12, \S 0.2$, at 41,554 .

38. See Steve Stockum, The Efficiencies Defense for Horizontal Mergers: What is the Government's Standard?, 61 ANTTrRUST L.J. 829, 829-31 (1993).

39. See $i d$. The efficiencies defense has not sufficed to win any adjudicated case, see id. at 829-30, and the Supreme Court has in fact never explicitly recognized the validity of the defense. See id. at 829. Note also that not even the efficiencies defense, weak as it is, allows anticompetitive effects in one market to be excused by efficiencies in another market. See infra notes 191-93 and accompanying text.

40. United States v. Philadelphia Nat'l Bank, 374 U.S. 321, 356 (1963). 
institutions, nevertheless enjoy a settled consumer preference, insulating them, to a marked degree, from competition . ... ${ }^{41}$

The Court thus concluded that the cluster of "commercial banking" products and services was a market "sufficiently mclusive to be ineaningful in terms of trade realities, ${ }^{, 42}$ and was therefore the relevant product market. ${ }^{43}$

However, while the Court explained that many of the individual products of a commercial bank faced little competition at the time, "the Court did not explain why these individual product markets should be grouped together" in a cluster market for purposes of merger review. ${ }^{44}$ The specific economic rationale behind the Court's adoption of the cluster market approach was thus left unstated, and lower courts were left with little practical guidance in the matter. ${ }^{45}$ As a result, "[i]nstead of invoking substantive standards, courts have often justified cluster definitions merely by relying on such undefined phrases as trade, commercial or economic 'reality," ${ }^{46}$ or on other criteria apparently unrelated to the question of whether or not the products and services included in the cluster were actually a single line of commerce. ${ }^{47}$

41. Id. at 356-57.

42. Id. at 357 (quoting Crown Zellerbach Corp. v. Federal Trade Comm'n, 296 F.2d 800, 811 (9th Cir. 1961)); see also United States v. Phillipsburg Nat'l Bank \& Trust Co., 399 U.S. 350, 359-62 (1970) (adopting the Philadelphia National holding that "commercial banking" composed a "distinct line of commerce" and including small banks as well as large banks in this category) (citations omitted).

43. See Philadelphia National, 374 U.S. at 357. Three years after Philadelphia National, the Court found another cluster niarket, this time in the niarket for accredited central station fire and burglar alarm services. See U.S. v. Grinnell Corp., 384 U.S. 563, 571-73 (1966) ("lump[ing] together" markets for burglar alarm services, fire alarm services, and other "property protection" services). The Court in Grinnell relied on the cluster market definition in Philadelphia National, and found that a "coinparable cluster of services" constituted the niarket for central station alarm services. Id. at 572 .

44. Ian Ayres, Note, Rationalizing Antitrust Cluster Markets, 95 YALE L.J. 109, 111 (1985).

45. See id. at 112; Jonathan R. Macey \& Geoffrey P. Miller, Nondeposit Deposits and the Future of Bank Regulation, 91 Mrcts. L. REV. 237, 265-66 (1992).

46. Ayres, supra note 44 , at 110 .

47. See id. at 112-13; see, e.g., American Med. Int'1, Inc., [1983-1987 Transfer Binder] Trade Reg. Rep. (CCH) II 22,170, at 23,040 (F.T.C. 1984) (approving cluster on the basis of "functional complementarity"); United States v. Hughes Tool Co., 415 F. Supp. 637, 640-42 (C.D. Cal. 1976) (approving cluster on the basis of common constituent technologies); In re The Grand Union Co., 102 F.T.C. 812, 1046 n.31 (1983) (approving cluster on the basis of census categories); In re Brunswick Corp., 94 F.T.C. 1174, 1258 (1979) (approving cluster on the basis of a trade association's recognition of an overall narket that includes producers of several different products). 
The best explanation for the existence of cluster markets, and the best justification for their use in merger review, is the theory of transactional complementarity. ${ }^{48}$ Products are said to be transactionally complementary if consumers usually choose to purchase them together ${ }^{49}$ If consumers do usually choose to purchase the different products together, then firms supplying only some of those products will not be able to compete effectively with firms supplying all of those products..$^{50}$ Competition will take

Scholars have also sometimes confused the usual definition of a product market-by substitutability and cross-elasticity-with the definition of a cluster market, which is characterized not by cross-elasticity between its constituent products (a safe deposit box, for instance, is not a viable substitute for a checking account), but by consumer demand for the cluster of services in toto, as opposed to demand for its constituent products separately. See, e.g., 4 EARL W. KINTNER, FEDERAL ANTTTRUST LAW \& 37.10, at 364-67 (1984) (referring to the product markets in United States v. Continental Can Co., 378 U.S. 441 (1964), and United States v. Aluminum Co. of Am., 377 U.S. 271 (1964), as cluster markets, even though the product markets in those cases were defined by cross-elasticity, not by transactional complementarity, see infra text accompanying notes 48-49; in Continental Can, for instance, the Court found that glass and metal containers were actively competitive as viable substitutes for each other, see 378 U.S. at 448-57, not that consumers usually chose to purchase glass containers and metal containers together).

48. For the seminal examination of transactional complementarity, see Ayres, supra note 44.

49. Specifically, products are transactionally complementary "if buying them froin a single firm significantly reduces consumers' transaction costs," thereby causing such products usually to be demanded together, and excluding from the market for those products firms that do not offer the whole group, or "cluster," of products which consumers choose to purchase together. Ayres, supra note 44, at 114-15. The operative distinction is between "significant" complementarity and insignificant complementarity; many consumers choose to purchase both oranges and motor oil at their local supermarket, but because many consumers still purchase oranges from fruit stands and motor oil froin gas stations, neither fruit stands nor gas stations are effectively foreclosed froin selling those products separately. The complementarity of those products is therefore insignificant, and aggregation of the markets for the two products into one cluster market would be inaccurate. On the other hand, virtually all consumers choose to purchase right shoes along with left shoes, and a firm selling only left shoes wonld be effectively foreclosed from competing in the market for shoes; complementarity between those two products is thus highly significant, and the two products are correctly analyzed as constituents of the same cluster market.

Notice that transactionally complementary products are defined as such on the basis of forces aggregating demand for those products; this is in contrast to tied goods, which are defined as such on the basis of forces aggregating supply of those products. The inquiry into whether products are transactionally complementary is thus the demand-side analogue to the inquiry, sometimes undertaken in tying cases, into whether the allegedly tied products are in fact separate products or are imstead a single product. See, e.g., United States v. Jerrold Elec. Corp., 187 F. Supp. 545, 559 (E.D. Pa. 1960), aff'd per curiam, 365 U.S. 567 (1961).

50. See Ayres, supra note 44, at 115; see also Peter Bronsteen, Product Market Definition in Commercial Bank Merger Cases, 30 ANTITRUST BULI. 677, 681-83 (1985) (defin- 
place only among those firms that supply the whole group, or "cluster," of products. ${ }^{51}$ In such a scenario, a court analyzing this

ing cluster markets as markets for "commodity bundles ... that are purchased jointly" and noting that a central attribute of such bundles is that "consumers react to a price increase for one or more items in the bundle as a price increase for the entire bundle"-a condition that the traditional banking cluster market may have met in 1963 but which it does not meet today).

Soine commentators argue that supply-side economies of scope may also lead to clustering if the cost advantages of producing an entire set of products, rather than only some of those products, are significant enough to provide producers of the entire cluster market power over partial producers. See Gregory E. Elliehausen \& John D. Wolken, Small Business Clustering of Financial Services and the Definition of Banking Markets for Antitrust Analysis, 37 ANTITRUST BULL. 707, 712 (1992). However, "while transactional complementarity necessitates joint purchase, economies of scope do not necessitate joint sale." Ayres, supra note 44, at 116. Thus, barring some separate exercise of market power, economies of scope could lead to clustering only if the producers of the entire cluster thereby are able to offer lower prices than partial producers or are able to lower purchasers' transaction costs; thus, even this form of clustering ultimately depends on consumers' choices to purchase the relevant products together rather than separately. In any case, economies of scope do not appear to be the cause of clustering in the banking industry. See Ellieliausen \& Wolken, supra, at 713.

Other commentators refer to cluster markets defined on the basis of "consumption complementarity." See, e.g., Roger D. Blair \& James A. Burt, Leveraging Monopoly Power Through Hospital Diversification, 1 STAN. J.L. BUS. \& FIN. 287, 294 n.40 (1995). That many consumers choose to consume two goods together, however, does not necessarily inean that those consumers will choose to purchase the two products together, or that firms producing one of the two goods will be unable effectively to compete with firms producing both of the two goods. Many consumers choose to consume potato chips together with cheese dip (and many supermarkets choose to carry both products), but many firms continue to produce only chips or only dip. Aggregation of the markets for the two products into one cluster inarket would thus be incorrect.

51. The cluster of products then functions as a single product for purposes of general product market definition; once the cluster has been defined, the court should then inquire into whether there are effective substitutes for the cluster as a whole, and then include both the cluster and any possible substitutes for it in the product market for purposes of antitrust analysis. However, because cluster markets often serve a relatively broad congeries of consumer demands, any effective substitute would very likely have to be a cluster itself, and in order to serve the same set of demands as the original cluster, a provider would very likely have to provide an aggregation of products so similar to the original cluster as to warrant treatinent, not as a substitute, but as merely another instance of the same cluster.

One commentator has argued that complementarity of products (whether supply or demand complementarity) should not be considered in market definition, but should be addressed after inarket definition, as a factor which facilitates or frustrates collusion (such as ease of entry). See Baker, supra note 35, at 129-40. Baker errs, however, in treating market definitions based on complementarity primarily as an alternative to market definition based on substitutability, rather than as a method for determining what "product" will be subject to substitutability analysis. The question is not whether "markets based on substitutability are to be preferred to the cluster based on complementarity," id. at 137, but whether substitutability analysis must be applied to one product or to a cluster of 
market for antitrust review purposes should cluster the submarkets for the transactionally complementary products together, so as to recognize not only ongoing competition among firms supplying the entire cluster, but also the exclusion from competition of those firms attempting to provide only part of the cluster. ${ }^{52}$ Only by clustering markets for transactionally complementary products can a court recognize competition where it in fact exists, ${ }^{53}$ and also recognize its absence where it is in fact absent.

The Court's cluster market definition in Philadelphia National was intended to reflect competitive conditions in the banking imdustry of 1963 and to acknowledge the extent to which the market for banking products and services was constrained-and protected-by regulation of the industry. ${ }^{54}$ That industry was predominantly one of "unit banking," im which most banks mamtained only one office, with limited branching. ${ }^{55}$ The industry operated within a strict regulatory framework which effectively prohibited interstate banking. ${ }^{56}$ Banks were prohibited from providing nonbanking products and services, ${ }^{57}$ and non-banks were prohibited

products.

52. See Ayres, supra note 44, at 117.

53. See generally Brown Shoe Co. v. United States, 370 U.S. 294, 326 (stating that the relevant market must be defined with sufficient accuracy to recognize competition where it actually exists).

54. See Michael P. Malloy, The Regulation of Banking 306 (1992).

55. Only $17.3 \%$ of banks in 1960 operated branches. See MACEY \& MILLER, supra note 10 , at 26 . By $1979,44.7 \%$ of banks did so. See id. In 1960, the country's 13,999 banks operated 11,106 branches. See U.S. DEP'T OF COMMERCE, BUREAU OF THE CENSUS, Statistical ABSTRACT OF THE UNITED STATES 1980, at 531 tbl. 873. By 1990, 12,819 banks operated 54,126 branches. See U.S. DEP'T OF COMMERCE, BUREAU OF THE CEnsus, Statistical ABSTRACT OF the UNITEd States 1992, at 495 tbl. 774.

Intrastate branching was limited, and in some states continues to be limited, by state legislation applied to national banks through the McFadden Act, 12 U.S.C. \& 36(c) (1994). The McFadden Act also generally prohibited interstate branching by national banks, see id., and by state-chartered member banks, see 12 U.S.C. § 321.

56. Interstate banking by bank holding companies' acquisition of banks in states other than home states was prohibited by the Douglas Amendment to the Bank Holding Company Act, unless the acquired bank's state legislature had explicitly authorized such an acquisition. See MACEY \& MILER, supra note 10, at 26-27. This prohibition has since been effectively repealed. See infra note 95 and accompanying text.

57. Specifically, banks are allowed to carry on only banking activities (as listed in the Glass-Steagall Act, 12 U.S.C. \& 24 (1994)), and those incidental activities "necessary to carry on the business of banking." Id. Among the activities that have been found to be prohibited to banks and bank holding companies are the provision of full-scale travel agency services, see Anold Tours, Inc. v. Camp, 472 F.2d 427 (1st Cir. 1972); retail sales data processing, see Nat'l Retailers Corp. v. Valley Nat'l Bank, 411 F. Supp 308 (D. Ariz. 1976), aff d, 604 F.2d 32 (9th Cir. 1979); insurance agency activities in communities 
from offering many banking products and services. ${ }^{58}$ Non-bank firms, such as thrifts, finance companies, credit card companies, and insurance companies ${ }^{59}$ had barely begun to enter markets for some banking products and services, and "the perception persisted that a commercial bank was a unique, full-service institution, somehow insulated from the serious competition of [its] non-bank rivals. ${ }^{\prime 60}$ In short, it was an industry whose products and services were treated as a group by law and regulation, and as a cluster by consumers.

Changes in the industry proceeded apace, however, and ten years later, while upholding the cluster market approach in another bank merger case, the Court felt constranied to add a significant qualification. In United States $v$. Connecticut National Bank, ${ }^{61}$ the Court stated that thrifts and commercial banks were "direct competitors in some submarkets,"62 and "fierce competitors" at that. ${ }^{63}$ The Court nonetheless upheld the cluster market approach, but did so only after acknowledging that the differences between

over 5,000 people, see Saxon v. Georgia Assoc. of Indep. Ins. Agents, 399 F.2d 1010 (5th Cir. 1968), but see First Union Banks, Establishment of Operating Subsidiaries to Engage in Insurance Agency Activities, OCC Letter 96-ML-08-009-015 (1996) (on file with author) (allowing national bank to engage in insurance sales nationwide, and requiring only technical agency functions to be performed in small towns); and the pledging of bank assets to secure deposits, see Yonkers v. Downey, 309 U.S. 590 (1940).

National banks and state member banks are also prohibited from underwriting, selling, and dealing in securities by the Glass-Steagall Act, 12 U.S.C. $\S \S 24,335$; banks are also prohibited from affiliation within a bank holding company with firms "engaged principally" in dealings im securities, see 12 U.S.C. $\$ 377$. State non-member banks' securities activities are regulated by the FDIC, 12 C.F.R. $\S 337.4$ (b), (c) (1996). Changes in the mdustry in the 1970s and 1980s significantly weakened the import of these prohibitions. See infra Section I.B.2. However, the trend had not yet begun to accelerate in 1963. See Melanie L. FeIN, SeCurTties Activities of BANKS, 1-14 to 1-18.2 (1991) (listing significant agency decisions loosening regulation under the Glass-Steagall Act).

58. For instance, banks held a legal monopoly over the market for both imdividual and commercial checking accounts, see United States v. Philadelphia Nat'l Bank, 374 U.S. 321,326 (1963), and thrifts were largely prohibited from offering commercial and real estate loans. See MACEY \& MILLER, supra note 10, at 468.

59. In this Note, firms which provide sone but not all of the products and services in the traditional banking cluster are referred to as "partial providers."

60. Eugene M. Katz, Determination of Line of Commerce for Bank Mergers: $A$ Contemporary View, 5 J.L. \& COM. 155, 160 (1985). In the early and mid-1960s, non-bank partial providers in general were just beginning to make inroads into commercial banks' traditional lines of business. See Shaffer, supra note 1, at 20 (describing increased competitive pressure on banks after 1966).

61. 418 U.S. 656 (1974).

62. Id. at 663 n.3.

63. Id. at 662 . 
the cluster of products and services offered by banks and those offered by thrifts and other partial providers were "perhaps not as sharply defined" as they had been ten years prior, in Philadelphia National. ${ }^{64}$ The Court went on to say that Philadelphia National did not hold that

[A] court may never consider savings banks and commercial banks as operating in the same line of commerce, no matter how similar their services and economic behavior. At some stage in the development of savings banks it will be unrealistic to distinguish them from commercial banks for purposes of the Clayton Act.... [But] we hold that such a point has not yet been reached. ${ }^{65}$

The Court has not revisited the issue to determine if that point has been reached in the quarter-century since Connecticut National was decided. Even though revolutionary changes have shaken the banking industry to the core, ${ }^{66}$ even though banks now face competition in virtually every subinarket from non-bank partial providers, ${ }^{67}$ and even though the legal and regulatory framework insulating banks froin that competition has been largely dismantled, ${ }^{68}$ no Supreme Court case-and only one federal ap-

64. Id. at 663 .

65. Id. at 666 .

66. See generally ROBERT E. LITAN, THE REVOLUTION IN U.S. FINANCE (1991) (discussing the causes and possible implications of a large-scale shifting of Americans' wealth from traditional banks and savings and loans to other financial intermediaries such as mutual funds); see also MACEY \& MULER, supra note 10, at 467-68 (questioning whether the passage of the Garn-St. Germain Act of 1982 might be "enough to boost thrifts over the Connecticut National threshold for the banking line of commerce").

67. See Robert E. Hauberg, Jr., Mergers and Acquisitions: Trends in Competitive Analysis, BANKNG EXPANSION REP., July 6, 1987, at 1 (describing how increased competition has altered the government's analysis of mergers); Eugene A. Ludwig, Antitrust and Banking, 49 ANTIIRUST BULL. 475, 476 (1996). Ludwig, the current Comptroller of the Currency, notes:

Unlike 35 years ago, there are now nonbank competitors for nearly all commercial bank services. Today, it is hard to identify market segments where banks maintain a clear competitive advantage, except perhaps in small business lending -in the form of lower information costs .... and in retail deposits ... in the form of federal deposit insurance. And the latter advantage is shared by other depository institutions. Indeed, one could argue that only bank innovativeness in entering new markets such as those for derivatives and various financial guarantees such as standby letters of credit has allowed them to remain major players in financial markets.

Id.

68. See infra Section I.B.2; see also MACEY \& MiLLER, supra note 10, at 467-69 (listing legislative changes since Philadelphia National). 
pellate case $^{69}$-has considered whether or not Philadelphia National's cluster market approach still "recognize[s] competition where, in fact, competition exists." ${ }^{.70}$

2. Structural and Legal Changes in the Banking Industry Since Philadelphia National. In the contemporary banking industry, the cluster market method is inaccurate; banks still dominate markets for some of the products and services in the traditional cluster, but thrifts and non-depository partial providers have made significant inroads into other markets. As noted above, the most prominent trend in the banking industry over the past two decades has been consolidation. In the past decade alone, the number of federallyinsured banking organizations declined more than $30 \%{ }^{71}$ Banking institutions tended to grow larger over the same period, ${ }^{72}$ and deposits became more concentrated in the largest institutions. ${ }^{73}$ This consolidation has occurred largely in response to other changes in the banking industry, both structural and legal, which have increased coinpetition in the industry and have forced banks to pursue greater efficiency.

Since the 1970s, banks' profit margins have been squeezed by several structural trends in the industry: disintermediation, globalization, and increased competition from thrifts and other partial providers. ${ }^{74}$ Banks have been dislodged from their historic role as the predominant financial intermediaries in the U.S. financial system, as depositors have moved their funds to money market funds, mutual and pension funds, and other depository institutions such as thrifts and credit unions. ${ }^{75}$ Large banks have also faced in-

69. A 1985 case in the Sixth Circuit, in which the court held, without significant comment, that the lower court's use of the cluster market method to analyze the acquisition at issue was not "clearly erroneous," is the only reported appellate case on point since Connecticut National. See United States v. Central State Bank, 817 F.2d 22, 24 (6th Cir. 1985) aff'g United States v. Central State Bank, 621 F. Supp. 1276, 1291 (W.D. Mich. 1985) (finding "that the relevant product market . . . is the cluster of products and services offered by commercial banks").

70. Brown Shoe Co. v. United States, 370 U.S. 294, 326 (1962).

71. See Amel, supra note 1, at 5 . Only a few non-federally-insured institutions continue to operate in the U.S., and their presence does not affect the overall trend toward consolidation. See id. at 1 .

72. The nuarket share of institutions controlling more than five billion dollars in deposits rose from $30 \%$ to over $50 \%$. See id. at 6 .

73. The share of deposits held by the top $1 \%$ of institutions, measured by size, rose froin $52.2 \%$ to $61.1 \%$. See id. at 9 .

74. See LITAN, supra note 66 , at 6-23.

75. See id. at 9-12; see also ALBERT M. WOJNILOWER, FINANCIAL INSTITUTIONS 
creased competition from foreign banks, as the financial services industry has undergone the same globalization as many other imdustries. ${ }^{76}$ Finally, banks have also faced increased competition in lending markets from thrifts ${ }^{77}$ and other lenders, such as finance compamies, ${ }^{78}$ and from the ongoing process of securitization of debt through commercial paper, mortgage-backed securities, and other debt securities. ${ }^{79}$

The imcreased competition which banks now face from thrifts and other partial providers ${ }^{80}$ has largely resulted from changes in the legal framework that formerly protected banks from competition in markets for many of the products and services included im the banking cluster market by the Philadelphia National Court. ${ }^{81}$ Banks' former legal monopoly over the market for checking accounts, the Philadelphia National Court's archetypal "banking product," 82 was effectively broken by the Depository Institutions Deregulation and Monetary Control Act of 1980 (DIDMCA), ${ }^{83}$

CANNOT COMPETE 4-5 (1990) (describing how relative freedom from govemment regulations made money markets attractive to investors).

76. See LITAN, supra note 66 , at 19-20. In the 1980s, foreign lending as a percent of total business lending in the U.S. rose from $15 \%$ to almost $30 \%$. See id. at 20 .

77. See MACEY \& MILLER, supra note 10, at 467-68 (recalling the Connecticut National Court's statement that thrifts did "not yet" warrant inclusion in the same product market as banks, and asking, "if not now, when?").

78. See LITAN, supra note 66 , at 18 (noting the increase in competition from finance companies).

79. See id. at 12-17. Banks have in turn capitalized on the new trend toward securitization by backing commercial paper issuers with standby letters of credit, but banks' margins on these instruments are significantly less than those on the lending business they have lost in the process. See id. at 17.

80. Competition from thrifts has waned in the last few years with the collapse of the thrift industry. See Rebel A. Cole et al., Bank and Nonbank Competition for Small Business Credit: Evidence from the 1987 and 1993 National Surveys of Small Business Finances, 82 FED. RES. BULL. 983, 984 (1996) (noting that thrifts lost almost half of their dollar share of the small business lending market between 1987 and 1993-but that the lost market share primarily accrued to other non-bank providers). The thrifts that remain, however, continue to represent significant competition. See infra notes $141-46$ and accompanying text. Moreover, competition from credit unions and other partial providers has increased over the past decade, see Cole et al., supra, at 984 , largely as a result of favorable administrative rulings. See Amel, supra note 1 , at 4.

81. The Court relied heavily upon this protectional framework in defining the cluster market in Philadelphia National: "Commercial banks . . . alone are permitted by law to accept demand deposits." United States v. Philadelphia Nat'l Bank, 374 U.S. 321, 326 (1963). Checking accounts were thus "entirely free of effective competition from products or services of other financial institutions." Id. at 356.

82. Id.

83. Pub. L. No. 96-221, 94 Stat. 132 (codified as amended in scattered sections of 12 
which authorized thrifts to offer negotiable order of withdrawal (NOW) accounts. ${ }^{84}$ The Garn-St. Germain Depository Institutions Act of $1982^{85}$ allowed thrifts to offer money-market accounts ${ }^{86}$ and to enter the markets for commercial lending and nonresidential real estate lending. ${ }^{87}$ The Competitive Equality Banking Act of $1987^{88}$ lifted limits on thrifts' interstate expansion, ${ }^{89}$ and allowed thrift holding companies to engage in activities formerly reserved to bank holding companies. ${ }^{90}$ The Financial Institutions Reform, Recovery and Enforcement Act of 1989 (FIRREA) ${ }^{91}$ then authorized bank holding comparies to acquire thrifts, ${ }^{92}$ and authorized thrifts to convert to commercial banks or merge with commercial banks, ${ }^{93}$ thereby escaping the thrift-specific regulatory requirements which remain.

Deregulation has also intensified competition within the banking industry. ${ }^{94}$ The Riegle-Neal Interstate Banking Act of 1994 opened up local banking markets to coinpetition from institutions headquartered all over the country, ${ }^{95}$ increasing intra-industry

\section{U.S.C.).}

84. 12 U.S.C. $\$ 1832$ (a) (1994). However, thrifts may only offer individual (i.e., noncommercial) NOW accounts. See id. \& 1832(a)(2).

85. Pub. L. No. 97-320, 96 Stat. 1469 (codified as amended in scattered sections of 12 U.S.C.).

86. See 12 U.S.C. $\$ 3503$ (1988) (omitted in 1994 U.S.C.).

87. See 12 U.S.C $\$ 1464(c)(1)$ (1994).

88. Pub. L. No. $100-86,101$ Stat. 552 (codified as amended in scattered sections of 12 U.S.C. (1988) (repealed 1989)).

89. See 12 U.S.C. \& 1730 (1988) (repealed 1989).

90. See id. $\S 1730 \mathrm{a}(\mathrm{c})(2)$.

1 91. Pub. L. No. $101-73,103$ Stat. 183 (codified as amended in scattered sections of 12 U.S.C.).

92. 12 U.S.C. § $1843(\mathrm{i})$ (1994).

93. 12 U.S.C. $\S \S 1815$ (d)(2)(G), 1815(d)(3) (1994). Thrifts are required to meet a number of capital and other requirements before conversion (often referred to as "Sasser conversions," after the provision's sponsor) or merger (often referred to as "Oakar conversions"). FISHER, supra note 17 , § 3.12 .1 , at $3: 97 \mathrm{nn} .25-26$. These requirements likely lessen somewhat the competitive impact of the conversion provisions on existing banks. However, a number of thrifts have successfully converted. See id.

Deregulation of the thrift industry has also generally accelerated the removal of regulatory limitations on commercial banks' opportumities for expansion and consolidation. See Lissa Lamkin Broome, The Influence of Enhanced Thrift Institution Powers on Commercial Bank Expansion, 67 N.C. L. REV. 795, 808-50 (1989).

94. See Helen A. Garten, Regulatory Growing Pains: A Perspective on Bank Regulation In a Deregulatory Age, 57 FORDHAM L. REv. 501, 502 (1989) ("[L]arge portions of traditional bank regulation, including the twin pillars of geographic and product restrictions, are crumbling rapidly." (citations omitted)).

95. 12 U.S.C. $\$ 1828$ (d) (1994). The passage of the Riegle-Neal Act was the capstone 
competition. Some bank product lines, such as credit cards, already face nationwide competition. ${ }^{96}$ Other submarkets, such as transaction accounts, have been specifically affected by legal changes such as those mcluded in DIDMCA, which authorized the payment of imterest on checking accounts, opening that submarket to more intense competition. ${ }^{77}$ The submarket for commercial lending to larger borrowers has been affected by increased securitization of debt, as noted above, and by court decisions allowing bank holding companies to engage im the securitized-debt markets themselves. ${ }^{98}$ In short, banks now face different levels of competition im different product lines; the traditional banking cluster market is fragmented.

3. The Antitrust Division's Abandonment of the Cluster Market Approach. In 1990, the Antitrust Division abandoned the cluster market method of product market definition in its review of bank mergers, and instituted a method of disaggregation of the traditional cluster market into smaller submarkets for specific products and services, with special emphasis on the market for commercial loans to small and medium-sized businesses. ${ }^{99}$ The Di-

of a long process whereby institutions had avoided the Douglas Amendment's restrictions on interstate banking through the vehicle of the "non-bank bank" and states had avoided those restrictions through mutual interstate banking compacts. See Michael P. Malloy, Nonbanks and Nondefinitions: New Challenges in Bank Regulatory Policy, 10 SETON HALL LEGIS. J. 1, 3-5 (1986); see also MACEY \& MILLER, supra note 10, at 32-33 (noting the rise of "regional banking compacts" in the 1980s).

96. See, e.g., Dennis W. Carlton \& Alan S. Frankel, The Antitrust Economics of Credit Card Networks, 63 ANTITRUST L.J. 643, 652-54 (1994) (noting the response of hundreds of issuers nationwide to AT\&T's introduction of a no-annual-fee Universal Card).

97. Depository Institutions Deregulation and Monetary Control Act of 1980, Pub. L. No. 96-221 § 207(b)(2), (3), 94 Stat. 132 (codified as amended im scattered sections of 12 U.S.C.); see also MACEY \& MILLER, supra note 10, at 31 (describing DIDMCA's place in the general deregulation of interest rates).

98. See Securities Indus. Ass'n v. Board of Governors of the Fed. Reserve Sys. (Bankers Trust II), 807 F.2d 1052, 1069-70 (D.C. Cir 1986) (holding that private offering of commercial paper does not constitute "underwriting" as proscribed by the GlassSteagall Act, 12 U.S.C. $\$ 378(a)(1)$ (1994)); Securities Indus. Ass'n. v. Board of Governors of the Fed. Reserve Sys. (Bankers Trust III), 839 F.2d 47, 66-67 (2d Cir. 1988) (holding that non-bank subsidiaries of bank holding companies may engage in bank-ineligible securities activities so long as revenues from those activities do not exceed $5 \%$ to $10 \%$ of the subsidiary's gross revenue).

99. See Katz, supra note 60, at 168-72. The Antitrust Division took this step in 1990 after several previous cases in which it had modified the traditional cluster market approach in one way or another, without explicitly disclaiming that approach. See id. 
vision debuted its new method in its first attempt to enjoin a bank merger in seven years, arguing that a proposed merger between First Hawaiian Inc. and First Interstate of Hawaii would substantially lessen competition in the inarket for commercial loans to small and medium-sized businesses in Hawaii. ${ }^{100}$ The Division entered its challenge after the Fed had already approved the acquisition under the cluster inarket approach. ${ }^{101}$ The Division required substantial divestitures as cure for the potential anticompetitive effects of the merger ${ }^{102}$ Since First Hawaiian, the Division has challenged, or threatened to challenge, numerous prospective bank mergers under its new disaggregated submarket analysis. ${ }^{103}$

The Fed, meanwhile, has resolutely maintained its use of the cluster market method of analysis. ${ }^{104}$ Thus the two agencies with primary responsibility for antitrust review of bank mergers are currently utilizing two very different methods of product market definition; as would be expected, the result in several cases has been approval of a proposed merger by the Fed, and a subsequent challenge of the same merger by the Antitrust Division. ${ }^{105}$

100. See Katz, supra note 20, at 4; Proposed Final Judgment, Stipulation, and Competitive Impact Statement, First Hawaiian, Inc., and First Interstate of Hawaii, Inc., 56 FED. REG. 10,916, 10,922-23 (1991) [hereinafter First Hawaiian, Proposed Final Judgment].

101. See First Hawaiian, Proposed Final Judgment, supra note 100, at 10,922; Order Approving the Acquisition of a Bank Holding Company, (First Hawaiian, Inc.), 77 FED. RES. BULL. 52, 53 (1991); Katz, supra note 20, at 4, 7.

102. See First Hawaiian, Proposed Final Judgment, supra note 100, at 10,924.

103. See, e.g., Proposed Final Judgment, Stipulation, and Coinpetitive Inpact Stateinent, U.S. v. Fleet/Norstar Financial Group, Inc., 56 FED. REG. 33,458 (1991) [hereinafter Fleet/Norstar, Proposed Final Judgment]; Proposed Final Judgment, Stipulation, and Competitive Impact Statement, U.S. v. Society Corp. and Ameritrust Corp., 57 FED. REG. 10,371 (1992) [hereinafter Society Corp, Proposed Final Judgment]; see also Margaret E. Guerin-Calvert, Current Merger Policy: Banking and ATM Network Mergers, 49 ANTITRUST BULL 289, 301 (1996) (listing resolutions of antitrust reviews of major bank mergers since 1990).

104. See Order Approving the Acquisition of a Bank Holding Company (First Hawaiian), supra note 101 , at 53; FISHER, supra note $17, \S 3.12$, at $3: 89$.

105. See, e.g., First Hawaiian, Proposed Final Judgment, supra note 100 at 10,922 ; Society Corp., Proposed Final Judgment, supra note 103 at 10,379 (DOJ challenge of merger after approval by Fed); Fleet/Norstar, Proposed Final Judgment, supra note 103, at 33,464 (same); Proposed Final Judgment, Stipulation, and Competitive Impact Statement, U.S. v. Texas Commerce Bancshares, Inc. and Texas Commerce Bank-Midland, N.A., 58 FED. REG. 15,361, 15,372 (1993) (DOJ challenge after approval by OCC). 


\section{Comparison ANd CRITICISM OF THE Two Methods}

\section{A. The Bank Merger Review Process}

The Antitrust Division receives hundreds of bank merger referrals yearly. To facilitate review of the proposed mergers, the Division uses a three-tiered review process. ${ }^{105}$ The first tier, called Screen A, is imtended to screen from further review those proposed mergers which will clearly not have any significant anticompetitive effects. Screen A calculates and compares the preand post-merger Herfindahl-Hirschman Index (HHI) ${ }^{107}$ values for the local geographic market, using deposits as a proxy for an institution's competitive strength ${ }^{108}$ and using the geographic market as defined by the Fed. ${ }^{109}$ For purposes of the Antitrust

106. See Greenspan, supra note 10 , at 17 ; Litan, supra note 10; Bank Merger Competitive Analysis Screening Process, OCC Advisory Letter 95-4, 1995 WL 444957, at *1*2 [hereinafter OCC Screening Letter].

107. The HHI value of a particular market is calculated by summing the squares of the individual market shares of all firms in the market. See MERGER GUIDELINES, supra note $12, \S 1.5$, at $41,557-58$.

For example, a market consisting of four firms with market shares of $30 \%$, $30 \%, 20 \%$ and $20 \%$ has an $\mathrm{HHI}$ of $2600\left(30^{2}+30^{2}+20^{2}+20^{2}=2600\right)$. The HHI ranges from 10,000 (in the case of a pure monopoly) to a number approaching zero (in the case of an atomistic market). Although it is desirable to include all firms in the calculation, lack of information about small firms is not critical because such firms do not affect the HHI significantly.

See id. $\S 1.5$ n.17. When reviewing mergers in industries other than banking, the Antitrust Division is unlikely to challenge mergers resulting in a post-merger HHI in the relevant market of less than 1000 , or a post-merger HHI of between 1000 and 1800, if the change in $\mathrm{HHI}$ caused by the merger is less than 100 index points. Id. $\S 1.51$. Mergers resulting in a post-merger HHI value between 1000 and 1800 and causing an increase of more than 100 index points will "raise significant competitive concerns" at the Division, and will be subject to further scrutiny; the same is true of mergers resulting in a post-merger HHI above 1800 and an increase of 50 or more mdex points. Id. The threshold at which the Division will find "significant competitive concems" differs when the merger under review is a bank merger. See infra note 111 and accompanying text.

108. Aggregate deposits from individuals, partnerships, and corporations ("IPC deposits") are the usual measure of deposits. See FisHER, supra note 17, § 3.7, at 3:54.

Note that the use of deposits as a proxy automatically excludes from consideration in this stage of review all partial providers who do not accept deposits, including finance companies, credit card companies, and so on. See infra notes 165-66 and accompanying text. The use of depository HHI also overlooks the importance of "nondeposit deposits" (instruments which perform the traditional functions of checking account deposits but which are structured so as to avoid federal regulation) and of the differences in distribution of these instruments between banks. See Macey \& Miller, supra note 45, at 265. Finally, the use of depository HHI measures has the potential to hide monopsonistic behavior in the purchase of deposits, as well as the potential monopolistic anticompetitive behavior in the extension of credit which is the primary concern of the Antitrust Division. See Bronsteen, supra note 50, at 689-94.

109. See OCC Screening Letter, supra note 106 , at $* 2-3, * 5$. If no Federal Reserve 
Division's HHI screening analysis, thrift deposits are either wholly excluded from the HHI calculation, if the ratio of the bank's total commercial and industrial (C\&I) loans to its total assets is less than $2 \%$, or are included at $100 \%$ of their actual value, if the C\&I loans-to-assets ratio is greater than $2 \% .{ }^{110}$ In order to fail Screen A, the post-merger HHI value nust exceed 1800 index points, and the increase from the pre-merger value to the postmerger value must exceed 200 points. ${ }^{111}$

The second tier of review, called Screen $B,{ }^{112}$ is much more stringent. It excludes thrift deposits from consideration entirely and utilizes smaller geographic markets if appropriate; ${ }^{113} \mathrm{HHI}$ calculations are then performed on the smaller market. The exclusion of thrift deposits from consideration and the use of a smaller geographic market makes it more likely that a proposed nerger will exhibit anticompetitive effects under the Screen B analysis. The Antitrust Division uses Screen A in all cases, and uses Screen B in most cases where the proposed merger is expected to fail Screen B with regard to any geographic market, or where the proposed merger might fail Screen A but for the effect on the HHI calculation of the inclusion of thrifts' deposits. ${ }^{114}$

If a proposed merger fails either or both of the two screens, then it is subject to deeper, disaggregated submarket analysis by the Division. ${ }^{115}$ The use of aggregate depository $\mathrm{HHI}$ analysis is

market exists, Ranally Metropolitan Areas (RMAs) or counties are used in its place. See id. at $* 5$.

110. See David S. Neill, New Antitrust Policies Add Complexity and Uncertainty to Bank Mergers, 17 BANK AND CORP. GOVERNANCE L. REP. 196, 196 (1996). This 2\% test is also applied to banks, see id. at 196, but few banks would be expected to fail the test.

111. See Greenspan, supra note 10, at 17; Litan, supra note 10 . Note that this test (often referred to as the "Brookhaven test," after the case in which it first appeared, see FISHER, supra note $17, \S 3.7$, at $3: 56$ ) is nominally more lenient than that imposed on mergers in other industries, where a merger will fail an HHI screening test if post-merger HHI is over 1800 and the increase is over 50 points, or if the post-merger HHI is between 1100 and 1800, and the increase is over 200 points. See supra note 107.

112. See Greenspan, supra note 10 , at 17 .

113. See OCC Screening Letter, supra note 106 , at $* 1$. These sinaller geographic areas usually correspond with Ranally Metropolitan Areas in urban areas, and with counties in rural areas. See Greenspan, supra note 10, at 17.

114. See Greenspan, supra note 10 , at 17.

115. The Antitnust Division may also subject a merger to deeper analysis if it involves two of the three largest banks in the market, if the merger receives substantial press coverage, or if the Division receives a credible protest from third parties. See SECTION of ANTTTRust LaW, American Bar Assoc., ANNUAl REVIEW OF 1994 ANTTTRUST 
supplemented at this stage by the use of output-based analyses of specific product markets, with special attention being paid to the inarket for loans to small and inedium-sized businesses. ${ }^{116}$ At this stage of merger review, the Division will also consider potential entry into the market by new competitors in response to any price increase, and may consider the competition of thrifts that do offer commercial loans. ${ }^{117}$ The Division will challenge a merger if analysis at this stage reveals the potential for significant anticompetitive effects in any product market. ${ }^{118}$ The initial screens, while important, are thus not fatal to a proposed transaction, as the Division often approves a transaction that fails one or both of the screening tests. ${ }^{119}$

The Fed's merger review process is shorter than that of the Antitrust Division; the Fed uses the same Screen A as the Division, but does not use Screen $B .{ }^{120}$ The Fed usually weights thrifts' deposits more heavily than the Division, regularly imcludimg them in the depository HHI calculation in Screen A at 50\%, and occasionally at weights as high as $75 \%$ or $100 \%$, of their actual value. ${ }^{121}$ The level of discounting is soinetimes determined by a C\&I loans-to-asset ratio test; the deposits of thrifts with C\&I loans-to-assets ratios of $0 \%$ to $3 \%$ are weighted at $50 \%$ of their actual value, the deposits of thrifts with C\&I loans-to-assets ratios

LAW DEVElopments 281 (James A. Wilson et al. eds., 1995).

116. See Litan, supra note 10. The Antitrust Division's concerns regarding mergers' effects on the market for loans to middle-market customers have heightened recently. See Neill, supra note 110 , at 199 . With regard to the markets for lending to small and medium-sized businesses, the Antitrust Division has also indicated that it may in some cases be concerned about potential anticompetitive effects of prospective mergers in "tiered" lending markets, that is, lending markets in which there are "one or two dominant firms and a fringe of small independent banks which may not be able to compete significantly." Id. at 198 (citation omitted). However, as Neill notes, the HHI itself is designed to accurately reflect market tiering, and thus the rationale behind imposing an additional, undefined inarket structure test is unclear. Id.

117. See Greenspan, supra note 10, at 17; Margaret E. Guerin-Calvert \& Janusz A. Ordover, The 1992 Agency Horizontal Merger Guidelines and the Department of Justice's Approach to Bank Merger Analysis, 37 ANTrTRUST BULL. 667, 679-80 (1992).

118. See Litan, supra note 10.

119. See id.

120. Greenspan, supra note 10, at 17. The OCC does the same. See OCC Screening Letter, supra note 106 , at $* 2$.

121. See, e.g., Country Bank Shares Corp., 83 FED. RES. Bull. 112 n.3 (1997) (weighing thrifts' deposits at 50\%); First Union Corp., 81 FED. RES. BuLL. 1118, 1119 n.9 (1995) (50\%); NationsBank Corp., 79 FED. RES. BULL. 969, 970 (1993) (50\%); Centura Banks, Inc., 76 FED. RES. BuLL. 869, 870 n.11 (1990) (75\%); BanPonce Corp., 77 FED. RES. BULL. 43, 44 n.9 (1991) (100\%). 
from $3 \%$ to $6 \%$ are weighted at $75 \%$, and the deposits of thrifts with C\&I loans-to-assets ratios above $6 \%$ are included at $100 \%$ of their actual value. ${ }^{122}$ The OCC and the FDIC discount thrifts' competitive effects even less than the Fed, usually imcluding them in the HHI screening calculation at $100 \%$ of their actual value..$^{123}$ The Fed will carry out a deeper, case-specific analysis if the proposed merger fails Screen A alone. ${ }^{124}$

\section{B. The Disaggregated Submarket Analysis}

The Division's disaggregation of the traditional cluster of banking products and services into its constituent submarkets for purposes of merger review is supported by theory and by empirical evidence. ${ }^{125}$ The cluster market method of product market defini-

122. See Neill, supra note 110 , at 196 . Where a bank and a thrift merge under the merger and conversion provision of 12 U.S.C. $\$ 1815(d)(3)$, the Fed includes the deposits of the thrift being converted at $100 \%$ of their actual value, because those deposits will become bank deposits through the merger, and includes the deposits of other thrifts in the market at a lesser weight. See, e.g., Huntington Bancshares Inc., 81 FED. RES. BULL. 47, 48 n.4 (1995); Norwest Corp., 78 FED. RES. BULL. 452, 452 n.5 (1992).

123. See FISHER, supra note $17, \S 3.12 .1$, at 3:91-92.

124. Unlike the Antitrust Division, the Fed will carry out this case-specific detailed analysis using the cluster market nethod of product market definition. See id. $\S 3.12$. The Federal Reserve has recently shown willingness to consider the market for small business lending in addition to the traditional cluster inarket at this stage; however, no policy change has been made. See infra note 169.

125. In addition to focusing on the subinarket for small business lending, the Antitrust Division is also sometimes concerned with the submarket for small business transaction (i.e., checking) accounts. See, e.g., First Hawaiian, Proposed Final Judgment, supra note 100, at 10,922; United States v. Central State Bank, 817 F.2d 22, 23 (1987). The Division's case with regard to disaggregation of this submarket is also strong. Most of the following theoretical and enpirical arguments in favor of disaggregation of the submarket for small business lending apply with similar force to the controversy over disaggregation of the market for small business transaction accounts. The market for small business transaction accounts is dominated by commercial banks; $86 \%$ of small businesses maintain liquid asset accounts (i.e., either checking or savings accounts) at commercial banks, while only $16 \%$ maintain such accounts at any non-bank provider. See Rebel A. Cole \& John D. Wolken, Financial Services Used by Small Businesses: Evidence from the 1993 National Survey of Small Business Finances, 81 FED. REs. BULl. 629, 656-58 tbl. A.4 (1995). The market is also overwhelmingly local; $95.7 \%$ of small businesses maintain checking accounts at local institutions. See Gregory E. Elliehausen \& John D. Wolken, Banking Markets and the Use of Financial Services by Small and Medium-Sized Businesses, 76 FED. RES. BULL. 801, 809 tbl. 6 (1990). Moreover, small business transaction accounts are legally still the exclusive domain of cominercial banks. See 12 U.S.C. $\& 1832(a)(2)$ (1988) (authorizing thrifts to provide individual, but not commercial, transaction accounts). Clustering of this submarket with other, less-concentrated subinarkets thus holds heightened potential to mask anticoinpetitive effects in this market. 
tion obfuscates the partial, submarket nature of partial providers' competition with commercial banks. The use of the cluster market method thus creates the possibility that merger review authorities might overlook significant concentrations im particular product lines and particular geographic areas, and that significant anticompetitive effects could follow, if certain banks were to merge without strategic divestitures. ${ }^{126}$ In the contemporary environment, approximation by aggregation may mask significant concentrations in bank-dommated product markets by conflating them with relatively diluted concentrations in product inarkets in which non-depository partial providers are significant competitors. ${ }^{127}$ The cluster market

126. See Bronsteen, supra note 50, at 686-87 (arguing that cluster approach should be abandoned); Note, The Line of Commerce for Commercial Bank Mergers: A ProductOriented Redefinition, 96 HARV. L. REV. 907, 907-08 (1983) (noting that cluster approach fails to recognize a merger's effect on competition im specific product lines).

127. See Bronsteen, supra note 50, at 686-87. To see this effect, consider the following example. In the first scenario, markets for all products in the traditional banking cluster of products are dominated by commercial banks:

Banking market, ca. 1963

\begin{tabular}{|c|c|c|c|c|}
\hline \multirow[b]{2}{*}{ Product: } & \multicolumn{4}{|c|}{ All product markets bank-dominated } \\
\hline & A & B & C & D \\
\hline & 20 & 25 & 20 & 45 \\
\hline Firms' & 20 & 25 & 20 & 20 \\
\hline Market & 20 & 25 & 20 & 15 \\
\hline Shares & 20 & 25 & 20 & 15 \\
\hline & 20 & & 20 & \\
\hline $\begin{array}{l}\mathrm{HHI}_{\text {product }} \\
\mathrm{HHI}_{\text {cluster }}\end{array}$ & 2000 & 2500 & 2000 & $\begin{array}{l}2875 \\
2344\end{array}$ \\
\hline
\end{tabular}

In the next scenario, some submarkets are still dominated by commercial banks, but partial providers have gamered significant market shares in other product submarkets:

\begin{tabular}{lllll} 
& \multicolumn{4}{c}{ Banking market, ca. 1996} \\
Product & B Bank-domimated & Non-bank-dominated \\
& & B & C & D \\
& 50 & 60 & 10 & 5 \\
Firms' & 30 & 20 & 10 & 5 \\
Market & 20 & 20 & 10 & 5 \\
Shares & & & 10 & 5 \\
& & & 10 & 5 \\
& & & etc. & etc. \\
HHI $_{\text {produet }}$ & 3800 & 4000 & 1000 & 500 \\
HHI $_{\text {clister }}$ & & & &
\end{tabular}


method's potential to mask anticompetitive effects is exacerbated by its effect on geographic market definition. Because the cluster market inethod requires the aggregation imto a single inarket of products that often are subject to competition from varying geographic areas, ${ }^{128}$ it also requires an approximation of the geographic area most representative of competition in the cluster inarket as a whole, even though the market for some products in some areas may be highly concentrated. ${ }^{129}$

Moreover, empirical evidence supports the Division's treatment of loans to sinall and medium-sized business as a distinct product market. The inarket for small business lending is distinctively "local" compared to markets for other banking products and services, ${ }^{130}$ small business generally rely almost exclusively on local commercial banks for working capital, ${ }^{131}$ and use fewer financial institutions in general. ${ }^{132}$ Continumg relationships between small businesses and their local banking institutions provide access to a greater amount of funds at a lower cost. ${ }^{133}$ Competition from non-bank and non-depository institutions is much weaker in the sinall business lending subinarket, especially with regard to unsecured sinall business credit, ${ }^{134}$ and debt securitization is not a viable option for sinall firms as it is for large ones. ${ }^{135}$ Thus, con-

$\mathrm{HHI}_{\text {cluster }}$ remains approximately the same in the two scenarios; but because it is diluted by the inclusion of the non-bank-dominated product markets in the latter scenario, it hides the fact that bank-dominated inarkets for products $\mathrm{A}$ and $\mathrm{B}$ are very highly concentrated.

128. For instance, a bank's credit card business may be nationwide, its trust service business may cover a significant portion of its state, and its commercial checking account business may be entirely local. See Stephen Davis, Trust-and Antitrust, INSTITUTIONAL INVESTOR, July 1996, at 66-67 (noting that “800 numbers, national credit card campaigns, [and] automated-teller-machine-networks . . . have pried open markets long dominated by local banks").

129. See W. Scott Frame, Examining Small Business Lending in Bank Antitrust Analysis, ECON. REv. (FED. RESERVE BANK OF ATLANTA), Mar./Apr. 1994, at 31, 33.

130. See id. at 32,35 .

131. See Elliehausen \& Wolken, supra note 125 , at 809 tbl. 6 . (finding that $91.5 \%$ of small and medium-sized businesses obtain credit from local institutions); see also Stephen A. Rhoades, Competition and Bank Mergers: Directions for Analysis from Available Evidence, 49 ANTITRUST BULL. 339, 345-6 (1996) (noting that $84 \%$ of sinall businesses use a local bank as their primary financial institution).

132. See Frame, supra note 129, at 35 .

133. See Mitchell Petersen \& Raghuram Rajan, The Benefits of Lending Relationships:

Evidence From Small Business Data, 49 J. FIN. 3, 3-37 (1994).

134. See Frame, supra note 129, at 35-36.

135. See Christopher Beshouri \& PETER Nigro, Securitization and Small Business Loans 1-4 (Office of the Comptroller of the Currency, Economic and Policy Analysis 
sumers of sinall business loans demand that product from a very limited geographic market, and often from one institution, even as they turn to institutions in a wider geographic area for other products and services, such as credit cards and equipinent financing. ${ }^{136}$ Finally, small business customers do not demand commercial banks' non-commercial products and services at all. ${ }^{137}$ Small business lending thus is not transactionally coinplementary to other products and services in the traditional cluster market, and should be analyzed as a separate market.

In addition to being transactionally noncomplementary, the market for small business lending is also a narket that continues to be dominated by commercial banks. ${ }^{138}$ The market exhibits mcreases in price when a local market becomes increasingly concentrated, ${ }^{139}$ and decreases in supply when a local market is served by smaller banks in multibank holding companies or by banks owned by out-of-state companies. ${ }^{140}$ The market for sinall

Paper Series, Working Paper No. 94-8, 1994).

136. See Elliehausen \& Wolken, supra note 125, at 809 . Fifty-four percent of small businesses acquire credit at their local institution, while only $14.3 \%$ acquire credit from nonlocal providers; only $1.7 \%$ of small busmesses acquire credit lines from nonlocal providers, as opposed to $22.8 \%$ from local providers. See id. On the other hand, $30.8 \%$ of small businesses acquire motor vehicle or equipment financing from local providers, while $8.7 \%$ acquire such financing froin non-local providers. See id.

137. See Note, supra note 126, at 919-21 (defining markets by separating the "household" market for banking products and services from the business market for those products and services).

138. See Frame, supra note 129, at 35-36. Even though banks' dollar share of the small business credit market declined by two points between 1987 and 1993, banks still hold over $60 \%$ of that market. See Cole et al., supra note 80 , at 984,988 tbl. 4. Moreover, after declining throughout the 1980s, banks' share of the market has held roughly steady since 1990. See id. at 986 chart 1 . The dominance of commercial banks in this market is likely due to many of the same factors that make small business lending transactionally non-complementary to other banking products and services, such as small businesses' limited ability to acquire funding from non-local providers, and the low crosselasticity of small business commercial bank loans with other sources of funding (such as debt securitization) that are viable substitutes for larger businesses.

139. See Timothy Hannan, Bank Commercial Loan Markets and the Role of Market Structure: Evidence from Surveys of Commercial Lending, 1991 J. BANKING \& FIN. 15, 133-49 (noting that the level of concentration in a local market for small business lending significantly affects the pricing of these loans).

140. See William R. Keeton, Multi-office Bank Lending to Small Businesses: Some New Evidence, ECON. REV. (FED. RESERVE BANK OF KANSAS CITY), at 45, 45 (1995). Specifically, the average ratio of small business loans to deposits at subsidiaries of multibank holding companies is $5.5 \%$, one percentage point less than that the same loan-deposit ratio at independent banks and at holding companies' lead banks. See id. at 51. The average loan-deposit ratio for banks owned by out-of-state bank holding companies is 
business lending is thus particularly susceptible to the potential anticompetitive effects of bank mergers-effects that may be hidden by the cluster market method.

\section{The Discounting and Exclusion of Thrifts and Nondepository Partial Providers from the Screening Analysis}

The effect of abandoning the cluster market method of product inarket definition would be ameliorated if the Antitrust Division were to give more meaningful consideration to the competitive effects of thrifts and other partial providers. There is little empirical justification for the discounting or exclusion of thrift deposits from the calculation of depository $\mathrm{HHI}$ for purposes of Screens A and B. Thrifts generally hold a small but significant share of the market for commercial loans, ${ }^{141}$ especially im certain regions. ${ }^{142}$ Moreover, thrifts very often represent significant potential competition. They often exhibit considerable unused capacity in commercial lending. ${ }^{143}$ They may readily utilize that extra capacity in response to anticompetitive behavior by $\mathrm{m}$-market banks $^{144}$ and, under FIRREA, they may be converted into commercial banks or merged into commercial banks. ${ }^{145}$ Thrifts also are significant competitors in markets for financial products and services to imdividuals and households. ${ }^{146}$

even lower, at $4.7 \%$. See id.

141. See Elliehausen \& Wolken supra note 125, at 660-61 tbl. A.5.

142. See Cole and Wolken, supra note 125, at 637, 665 tbl. A.6 (noting strength of thrift industry in New England).

143. See Katz, supra note 60 , at 162 (noting that in pricing loans, "commercial banks cannot ignore the fact that there is a vast pool of funds available from thrifts to satisfy business borrowers' demands"); FISHER, supra note 17, $\S 3.12 .1$, at 3:90-98. This is true even in light of statutory limits on thrifts' commercial lending powers; thrifts are allowed to commit $10 \%$ of their assets to commercial lending, and to commit another $10 \%$ of their assets to small busimess lending, see 12 U.S.C. \& 1464(c)(2)(A) (1994). Since the onset of the thrift crisis in the late 1980s, thrifts have not generally lent amounts sufficient to reach these statutory ceilings, and thus still represent potential competition. See FISHER, supra note $17, \S 3.12 .1$, at $3: 90-98$. Moreover, some banking markets feature numerous commercial banks whose loan portfolios include large amounts of commercial real estate lending, and whose primary competitors therefore are thrifts; many banking markets in California and Texas, for instance, fit this profile. See id.

144. See FisHER, supra note 17 , § 3.12 .1 , at 3:90-98.

145. See id.; see also 12 U.S.C. $\$ 1815(d)(2)(G)$ (1994) (authorizing conversion of thrifts into banks, under certain conditions); id. $\$ 1815$ (d)(3) (authorizing merger of thrifts into banks, under certain conditions).

146. See Arthur B. Kennickell et al., Family Finances in the U.S.: Recent Evidence from the Survey of Consumer Finances, 83 FED. RES. BULL. 1, 20 tbl. 13 (1997) (noting 
There is also little theoretical justification for the discounting or exclusion of thrifts generally. ${ }^{147}$ The Antitrust Division's discounting of thrifts' deposits at the screening stage is predicated on the assumption that those deposits do not in fact accurately represent thrifts' ability to compete with banks. ${ }^{148}$ That assumption is valid only in the context of the traditional banking cluster market, where thrifts' competition truly was of a partial nature with regard to the banking cluster market. If, as the Antitrust Division asserts, that cluster market no longer exists, ${ }^{149}$ and the product market utilized at the screening stage is merely an aggregation of related product markets for screening purposes, then thrifts' competition is no longer "partial" at all; they are merely one sort of competitor in some of the product markets being treated together at the screening stage. In that context, the need for discounting disappears.

In other words, if the Antitrust Division chooses to aggregate a group of non-complementary products merely in order to facilitate a screening process, then the fact that some firms provide one subset of that group, some firms another subset, and other firms a third subset, does not require that the measurement of each firm's share of the aggregate market be weighted according to the proportion of the entire set of products that it provides. If the indicia (i.e., deposits) being used to measure each firm's participation in the markets for the screening group of products accurately represent each firm's ability to provide substitutes for soine of the products provided by each other firm, then the firm's share of the aggregated markets for the screening group, ineasured by those indicia, will be accurately representative of its competitive effect, and there will be no need for weighing. ${ }^{150}$ The discounting of thrifts' deposits for HHI purposes was intended to account for those institutions' mability to fully compete in the traditional clus-

\footnotetext{
that, even after the collapse of the thrift industry in the late 1980s and early 1990s, thrifts still hold $11.3 \%$ of the inarket for consumer debt).

147. See FISHER, supra note 17, § 3.12.1, at 3:90-98.

148. See id.

149. See supra Section I.B.2.

150.

If, for example, one defines a hypothetical product market as consisting of two [non-compleinentary] products, there appears to be no economic rationale for discounting the inarket share of an institution that offers only one of the products or decides to concentrate its marketing efforts on only one.

FISHER, supra note 17, § 3.12.1, at 3:97.
} 
ter market, ${ }^{151}$ the Antitrust Division's current approach to product market definition in the antitrust analysis of bank mergers, however, is effectively premised on the assertion that many products and services that were transactionally complementary and deserving of treatment as a cluster market at the time of Philadelphia National are no longer so. If this is true, then the aggregation of the markets for those products and services at the screening stage is no longer compelled by narket realities; it is merely a jerry-rigged approximation of both a product market and a geographic market for screening purposes, and should be treated as such. Doing so requires that thrifts' deposits no longer be heavily discounted in, or excluded entirely from, HHI calculations at the screening stage; if the Antitrust Division discovers special circumstances indicating that depository HHI overestimates thrifts' abilities to compete for at least part of the traditional banking cluster in a particular case, then that fact alone could serve as grounds for taking the review of the proposed merger to the case-specific stage of analysis. ${ }^{152}$

Moreover, if thrifts are to be discounted or excluded from the screening analysis, there are significant problems with the use of C\&I loans-to-assets ratios as the test for such discounting or exclusion. First, such tests generally fail to account for thrifts' and other institutions' potential to enter the market in response to the imposition of an SSNPI. In the antitrust review of mergers in most industries, "even firms that do not currently offer the product in question ... are included in the market calculations if they have the technological capability to provide the product without the expenditure to" the imposition of an SSNPI. ${ }^{153}$ The C\&I loansto-assets ratio test used by the Antitrust Division, however, excludes from consideration those institutions with C\&I loans-toassets ratios below $2 \%$, even though those institutions are likely to have the capacity to enter the market-and even though those firms are in fact participants in the market. ${ }^{154}$ Also, the choice of

151. See, e.g., United States v. Connecticut Nat'l Bank, 418 U.S. 656, 664 (1974) (reversing a lower court decision which concluded that commercial and savings banks occupied the same "line of commerce," on grounds that commercial banks offer a unique "cluster of services").

152. See FISHER, supra note $17, \S 3.12 .1$, at 3:90-98 (arguing that the discounting of thrift deposits is "antithetical to the premise of a single niarket").

153. Peter E. Greene, DOJ Quietly Introduces New '2 Percent Test' for Bank Merger Analysis, BANKInG POL. REP., Oct. 21, 1996, at 1.

154. See id. In one case, in fact, the C\&I loans-to-assets ratio of one institution ex- 
one value $-2 \%$-as the determinant of an institution's inclusion or exclusion from the analysis is unnecessarily arbitrary and rigid; ${ }^{155}$ if a C\&I loans-to-assets ratio test is to be used, it should at a minimum allow for the inclusion, at a discount, of institutions with varying ratios, as does the Federal Reserve's test for inclusion in the depository HHI screening analysis. Finally, an institution's low C\&I loans-to-assets ratio "may also reflect weak market demand conditions [and] may be indicative of nothing more than the existence of excess lending capacity in the inarket as a whole."156 If a C\&I loans-to-assets ratio test is to be used, it "should be adjusted to account for local market demand characteristics."157

Because failure of either of the two initial screens will subject a proposed merger to further scrutiny, ${ }^{158}$ the use of Screen B in any case where a proposed inerger would be expected to fail Screen A but for the inclusion of thrifts' deposits effectively excludes thrifts' deposits from consideration for purposes of screening. Screen $A$ is thus rendered superfluous and noot. Any inclusion of thrifts in the screening analysis, in order to be ineaningful, will therefore have to be complemented by the removal of Screen $B$ from the analysis.

The Antitrust Division addresses the issue of inclusion of nondepository partial providers in the screening process in a roundabout fashion. As noted above, the HHI test used for bank mergers differs from the test used for analysis of mergers in other industries; ${ }^{159}$ the test used for mergers in other imdustries requires that the difference between pre- and post-inerger HHI values be less than fifty index points, while the test used for bank mergers requires that the difference be less than 200 points. ${ }^{160}$ The Division's requirement that the difference between pre- and post-merger HHI values for a proposed bank merger be less than 200 points is intended to take into account the competitive effects of partial providers who are not directly considered at the screening stage. ${ }^{161}$

cluded from consideration rose to over $4 \%$ in the three years after the merger. See id.

155. See id.

156. Neill, supra note 110 , at 197.

157. Id.

158. See Greenspan, supra note 10 , at 17.

159. See supra notes $106-111$ and accompanying text.

160. See Merger Guidelines, supra note 12, § 1.51, at 38.

161. The Division has in fact indicated a willingness to recognize competition from 
As with the discounting and exclusion of thrifts from the screening analysis, there is little theoretical or empirical justification for treating nondepository partial providers (such as finance companies and leasing companies) in so rigid a fashion. Over a quarter of small businesses use nondepository suppliers of financial services, ${ }^{162}$ and one out of every five businesses obtain loans, credit lines, or leases from nondepository financial institutions. ${ }^{163}$ This does not establish that nondepository institutions will be significant competitors in all or even most markets; but it does indicate that such institutions will be significant competitors in a significant number of inarkets, and that a more case-specific method of assessing their competitiveness is warranted.

The Antitrust Division's use of the Brookhaven test ${ }^{164}$ to address partial providers' effects on competition is theoretically flawed in essentially the same way as its exclusion of thrifts from the HHI calculation. The more lenient Brookhaven test was based on a characterization of partial providers' conipetitive effects in the traditional banking cluster market; again, if, as the Antitrust Division now asserts, that cluster market definition is no longer analytically sound, then partial providers' different competitive effects in various financial product markets (auto loans, home improvement loans, credit cards, and so on) sliould be addressed directly.

It is at this point that the slortcomings of the use of deposits as a proxy for output-based measures in the HHI analysis become apparent; nondepository partial providers by definition will not be able to acquire a significant share of deposits by offering higher interest rates in response to a bank's imposition of an SSNPI, ${ }^{165}$

non-bank, non-depository institutions, but only if the prospective merger partners adduce sufficient evidence to show that such institutions do in fact significantly compete in the relevant submarket. See Greenspan, supra note 10, at 18.

162. See Elliehausen \& Wolken, supra note 125, at 652 tbl. A.3.

163. See id. at 662 .

164. See supra note 111 and accompanying text.

165. An SSNPI imposed by a bank in the market for deposits wonld take the form of a decrease in the interest rates paid for deposits. This action would thus be essentially monopsonistic or oligopsonistic, rather than monopolistic or oligopolistic. The illegality of such monopsonistic or oligopsonistic action under the antitrust laws is nonetheless clear. See, e.g., Mandeville Island Farms, Inc. v. American Crystal Sugar Co., 334 U.S. 219, 235 (1948) (stating that oligopsonistic price-fixing scheme "is the sort of combination condemned by the [Sherman] Act, even though the price-fixing was by purchasers, and the persons ... injured ... are sellers, not customers or consumers") (citations omitted). 
but they may well be able to acquire a significant share of auto loans, or of credit card accounts, or of a number of other submarkets of the traditional banking cluster market, in response to banks' imposition of an SSNPI in these markets. ${ }^{166}$ In fact, partial providers are steadily gaining market share in product markets formerly dominated by commercial banks. ${ }^{167}$ Using deposits as a proxy for banks' market power "is tantamount to using the amount of iron ore bought by a steel company, rather than the steel produced by the company, as a measure of its market share."168 Accordingly, banks' inarket share should be measured by the same sort of output-based measures used in other industries; in the market for small business lending, for instance, that output measure would simply be banks' respective volumes of lending to sunall businesses within the relevant geographic market-figures which banks can readily provide, or which can be estimated on the basis of data already disclosed in banks' call reports. ${ }^{169}$

166. For instance, if banks' rates on auto loans in a given geographic market were to increase by one point, while auto financing rates stayed the same, one would expect consumers to substitute funds from financing companies for funds from banks to a significant extent; the same would hold true for hoine improvement loans, credit cards, and other submarkets of the traditional banking cluster. The fact that many partial providers depend on credit from banks for their working capital does not contraindicate such an effect, because most such partial providers (loan companies, auto financing companies, credit card companies, etc.) have access to credit from banks outside their local geographic market. These firms' supply of funds thus would not be affected by the SSNPI imposed by the banks with which they compete on a local basis.

167. See James B. Andorfer, Nonbanks Aiming for King of the Hill, AM. BANKER, Sept. 9, 1996, at 4A.

168. FISHER, supra note $17, \S 3.7$, at 3:54.

169. See Frame, supra note 129, at 38. Call reports provide lending data for the institution as a whole, not the branch-specific information often necessary to assess lending within a particular geographic market. However, branch-specific figures can be estimated by assigning to each branch a share of the institution's total lending proportionate to that branch's share of the institution's total deposits. See id.

The Antitrust Division suggests but does not require that market-specific small business lending data be provided, see OCC Screening Letter, supra note 106, at *4; the Fed so suggests on occasion, but not in any regular or predictable fashion, largely because the Fed has not been given the power to compel disclosure of this data for all competitors in the market under review. See Alan S. Blinder, Antitrust and Banking, 49 ANTIrRUST BULL. 447, 450 (1996). Blinder, the former Vice Chairman of the Board of Governors of the Federal Reserve, argues that "bank deposits are the absolutely worst thing to look at in a competitive analysis-until you consider the alternatives." Id. However, Blinder intimates that the Fed might in the future be willing to abandon the use of deposits as a proxy. See id. 
The changes in the industry since Philadelphia National have led the Fed to include thrifts and other partial providers in aggregate depository HHI during the screening stage of its merger review analysis, at a discount often determined on the basis of a C\&I loans-to-assets ratio test. ${ }^{170}$ At the latter, case-specific stage of analysis, however, the Fed has maintained the cluster market analysis that is explicitly intended for an industry in which thrifts and partial providers do not count. If thrifts' and other partial providers' deposits (as proxy for their competition in specific product markets) are to be included in calculation of aggregate depository HHI, then to decline to analyze those specific product markets at the case-specific stage is inconsistent; ${ }^{171}$ thrifts and credit unions, by definition, compete with commercial banks only in product niarkets constituting fragments of the "cluster" of products and services that banks offer, and their coinpetition with banks is felt only in those particular subniarkets. As explained in the previous section, approximation by aggregation may niask significant concentrations in bank-dominated product inarkets by conflating them with relatively diluted concentrations in non-bank-dominated product inarkets, and may thus overlook significant concentrations in particular product lines and particular geographic areas that

170. See supra notes 121-23 and accompanying text. The Fed's use of a C\&I loansto-assets ratio suffers from many of the same problems that are attendant upon the Antitrust Division's use of such tests; for instance, they do not account for firms' potential to respond to the imposition of an SSNPI, and they do not take into account local market demand characteristics. See supra notes 153-57 and accompanying text. The Fed's threetiered test, see supra notes 121-24 and accompanying text, is however less arbitrary and rigid than that of the Antitrust Division. The Fed's test also provides more meaningful consideration of thrifts' competition by including thrifts in the screening analysis at no less than $50 \%$ of deposits; the Antitrust Division's test, on the contrary, either imcludes or excludes thrifts' deposits entirely. See Neill, supra note 110, at 196.

171. The inclusion of thrifts is consistent with the maintenance of the traditional cluster market approach only if one assumes that all cases present the same mix of partial providers, that the mix is not one in which banks still hold a dominant position in at least one of the submarkets being included in aggregate HHI, and that the competitive effects of these firms are otherwise accounted for in the screening analysis. If any one of these assumptions is not valid, then the cluster market approach will retain the potential to mask significant anticompetitive effects. See supra notes 125-40 and accompanying text. In fact, the mix of partial providers varies from case to case, see supra notes $141-46$ and accompanying text, and banks do hold a dominant position in the market for small business lending. See supra notes 126-27 and accompanying text. Moreover, the Fed's approximation of the competitive effect of partial providers through use of the 1800/200 HHI test suffers from the same shortcomings as the Antitrust Division's use of that test. See supra notes 108-09 and accompanying text. 
could result from some mergers. ${ }^{12}$ These concentrations, if overlooked, could result in the anticompetitive exercise of market power by the survivor of the merger, to the detriment of competition and consumers.

This is especially true with regard to the market for commercial lending to small and medium-sized busmesses, where opportumities for substitution in response to the imposition of an SSNPI are particularly limited. ${ }^{173}$ Because commercial lending is not transactionally complementary to other products and services in the traditional banking cluster inarket, the submarket for commercial lending should be considered independently of the other submarkets so as to "recognize competition where, in fact, competition exists." ${ }^{\prime 174}$

\section{A SUGgESTION FOR RECONCILIATION OF THE TWO APPROACHES}

\section{A. A Proposal for Reconciliation}

As noted in the previous section, the Antitrust Division utilizes a merger review procedure in which prospective mergers are first screened for anticompetitive effects using an HHI calculation based on deposits as a proxy for market share. The product market at the screening stages is defined as the traditional cluster market, and thrifts' deposits are discounted or excluded from the HHI calculation. ${ }^{175}$ If a proposed merger fails either of the Division's initial screens, it is then subject to a more detailed analysis in which the traditional cluster market approach is abandoned im favor of the disaggregated subinarket approach. ${ }^{176}$ The Fed, on the other hand, uses only Screen A, again using deposits as a proxy for market share in a product market defined as the traditional cluster of banking products and services, and usually including thrifts' deposits at a much higher weight than does the Division. As at the Division, if a merger fails Screen $A$, then it will be subject to more detailed review. However, the Fed maintams the

\footnotetext{
172. See supra notes $121-26$ and accompanying text.

173. See supra notes $130-37$ and accompanying text.

174. Brown Shoe Co. v. United States, 370 U.S. 294, 326 (1962).

175. See supra notes $107-11$ and accompanying text.

176. See supra note $\mathbf{1 1 5}$ and accompanying text.
} 
traditional cluster market approach to product market definition even for purposes of this deeper analysis.

The Fed's approach could be brought into line with the Antitrust Division's, and the inconsistency ${ }^{177}$ in the Fed's cluster market analysis removed, by disaggregating the traditional cluster market and directly analyzing specific product markets at the final, case-specific stage of analysis. This disaggregation would reinove the potential of the cluster market method in the modern banking industry to mask significant anticompetitive effects of a proposed merger. ${ }^{178}$ It would also provide the flexibility to deal with the partial providers of financial products and services that have made significant inroads into inany submarkets of the traditional cluster, and the new kinds of partial providers that continue to appear, ${ }^{179}$ and thus ensure that those firms' market shares are not underrepresented in close cases.

This disaggregation might increase transaction costs of a proposed inerger, as potential merger partners could no longer use the cluster market method as shorthand for a more detailed, product-specific analysis of likely anticompetitive effects of their merger. ${ }^{180}$ However, the disaggregative approach need not be as fraught with uncertainty as some practitioners have feared. ${ }^{181}$ The necessary data for testing specific bank product markets are not significantly more unwieldy than the data mvolved in analyzing product markets in other industries. In addition, the Antitrust Division has enumerated what kinds of information are relevant,

177. See supra notes $169-72$ and accompanying text.

178. See Note, supra note 126 , at 925 .

179. See id. A good example of new partial providers is the proliferation of "e-cash" institutions, which act as financial intermediaries to facilitate convenient and secure nronetary transactions over the Internet and through other computer networks, and which provide products very similar in structure to traditional banking products. See generally, Penny Lunt, Payments on the 'Net: How Many? How Safe?, A.B.A. BANKING J., Nov. 1995, at 46 (detailing the rise in the Intemet banking system). Such institutions have the potential to make relevant geographic markets for some products and services global, even with regard to financial institutions in the smallest towns, and present numerous regulatory challeuges. See generally D. Lee Falls, Dateline 2005: Does Banking on the Internet Need to Be Regulated?, BANKING POL'Y. REPT., Dec. 18, 1995, at 1.

180. See Frame, supra note 129, at 37.

181. See, e.g., Division Official, Bank Counsellor Cross Swords Over Bank Merger Reviews, Antitrust and Trade Reg. Rep. (BNA) No. 1572, at 17, July 2, 1992 (quoting a banking attorney's assertion that prospective inerger partners "have no idea of what's going to happen in any imdividual case. That makes the process more difficult and more expensive."). 
making the process more predictable. ${ }^{182}$ Reconciliation of the two agencies' different methods of product market definition would also alleviate the need to produce different data in support of applications to the different agencies for merger approval.

If after a period of transition to the disaggregative approach, significant extra transaction costs would remain, then from an economic policy standpoint, the question would become whether or not these increased transaction costs are greater or less than the deadweight social costs of any anticompetitive effects that use of the disaggregative submarket method would prevent. ${ }^{183}$ While a detailed answer to this question is beyond the scope of this Note, it may be noted that as consolidation in the banking industry continues, potential anticompetitive effects of that consolidation may be expected to arise more frequently. ${ }^{184}$

The Antitrust Division, meanwhile, should at a minimum do away with Screen $B,{ }^{185}$ and should regularly include thrifts' deposits in the HHI calculation in Screen A at a lesser discount, as does the Fed, or at their full weight, as do the OCC and the FDIC. ${ }^{186}$ Both the Antitrust Division and the federal banking agencies should also move from the use of aggregate depository HHI to direct measurement of market shares in particular product lines such as sinall business lending (as the rationale behind the disaggregative method would seem to require). ${ }^{187}$

\section{B. The Vestigial Philadelphia National Precedent}

The issue of product market definition in the antitrust analysis of bank mergers has very rarely been litigated in court since First Hawaiian, ${ }^{188}$ because prospective merger partners are loath to

182. See Guerin-Calvert \& Ordover, supra note 117, at 678.

183. The deadweight social cost of the anticompetitive effects of a merger is the aggregate loss of consumer surplus that results. See generally VISCUSI ET AL., supra note 3, at 75-76 (defining and discussing deadweight social costs).

184. An omen of possible future anticompetitive effects may be seen in the fact that from 1984 to 1994, the average HHI for urban banking markets increased by 181 index points. The average HHI for rural markets, already highly concentrated, increased 140 index points in the same period. See Amel, supra note 1, at 14.

185. See supra note 152 and accompanying text.

186. See supra notes $141-57$ and accompanying text.

187. See supra notes $159-63$ and accompanying text.

188. In all recent cases except United States v. Central State Bank, 621 F. Supp. 1276 (1985), prospective merger partners have simply acceded to the Antitrust Division's demands for divestitures, and accepted a consent decree. See also Guerin-Calvert, supra 
hold up a merger in order to contest the point. ${ }^{189}$ Thus, if the Fed were to abandon the cluster market approach as has the Antitrust Division, then the holding in Philadelphia National would essentially be a dead letter.

However, if the issue were to be brought to substantive review, the structural and legal changes in the banking industry would warrant a rejection of the cluster market method of product market definition. The cluster inarket method no longer "recognizes competition where, in fact, competition exists." 190 Specific authority for rejection of the cluster market approach is found im Philadelphia National itself; the Court there rejected the argument that "anticompetitive effects in one market could be justified by procompetitive consequences in another" market. ${ }^{191}$ This, however, is precisely what the cluster market method of product market definition does in today's banking industry: it obscures-and on occasion approves-large market shares in concentrated markets by conflating them with smaller market shares in less-concentrated markets. ${ }^{192}$ A court reviewing the agencies' definition of the product market in a bank merger case should therefore accept the Connecticut National Court's invitation to update the law on this point, ${ }^{193}$ and hold that disaggregation of the traditional banking cluster market is consistent with the dictates of the Clayton Act.

note 103, at 300 (noting that all the lawsuits seeking to enjoin bank mergers filed by DOJ between 1990 and 1993 were settled by divestitures and were not litigated, and that since then, DOJ has not even had to file lawsuits to cause prospective merger partners to accede to divestitures).

189. See Davis, supra note 128 , at 67.

190. Brown Shoe Co. v. United States, 370 U.S. 294, 326 (1962).

191. United States v. Philadelphia Nat'l Bank, 374 U.S. 321,370 (1963); see also Clark C. Havighurst, Antitrust Issues in the Joint Purchasing of Health Care, 1995 UTAH L. REV. $430-35$ (noting that cluster markets as applied in health services markets "effectively circumvent[]" the rule stated in Philadelphia National). Professor Havighurst also notes that improperly-defined cluster markets, by obscuring the potential anticoinpetitive effects of a merger, are as illegitimate as the archaic "worthy purposes" defense. See id. at 435 n.77 \& 424 n. 43 .

The current Coinptroller of the Currency has in fact argued that anticompetitive effects in some markets should perhaps be excused by procompetitive effects in other markets, despite Philadelphia National's apparently plain foreclosure of this approach. See Ludwig, supra note 67 , at 477 ("[W] hile the focus in judging the effects of potential mergers has been on the 'most dainaged market,' it is not clear that a merger that strengthens competition in most of the markets in which a bank competes should be denied because of anticompetitive effects in a single market.").

192. See supra notes $126-28$ and accompanying text.

193. See supra notes $61-70$ and accompanying text. 


\section{CONCLUSION}

Even though the number of bank merger applications challenged by the Federal Reserve or the Antitrust Division is very small, ${ }^{194}$ prospective partners still face some uncertainty regarding an anticipated transaction. ${ }^{195}$ Some of this uncertainty would be alleviated if the Federal Reserve were to abandon its anachronistic cluster market approach to the antitrust analysis of bank mergers, and if the Antitrust Division were to enubrace more meaningful consideration of the competitive effects of thrifts and other partial providers. This snall measure of added predictability would be complemented by the increased flexibility to account for new partial providers and the greater analytical accuracy that these changes would bring. A compreliensive refinement of product market definition in the antitrust analysis of bank nergers would thus be a beneficial adjustment for commercial banks, non-bank competitors, regulators, and-ultimately-competition and consumers.

194. See Litan, supra note 10; Bingaman, supra note 2, it 469 (noting that during fiscal year 1995, the Antitrust Division reviewed 1897 bank mergers, of which 1200 required competition analysis; only five mergers, however, raised "serious competitive concerns" requiring curative divestitures).

195. See Glassman, supra note 3, at 4 . 